\title{
EXPERIMENTAL ANALYSIS OF DIFFERENT INSULATED FAÇADE TECHNOLOGIES IN SUMMER CONDITION
}

\author{
Graziano Salvalai, ${ }^{1} \mathrm{PhD}$, Marta Maria Sesana, ${ }^{1} \mathrm{PhD}$
}

\begin{abstract}
At the present, the ventilated façade is one of the most widely used and most innovative systems characterized by different energy saving features, but due to its complexity, the real performances are difficult to predict by numerical analysis. This work shows the results of the monitoring campaign conducted on two Cross Laminated Timber (CLT) test boxes equipped with different thermal coat technologies to realize the performances comparisons. In particular, the investigation focus on the evaluation of surface temperatures of the different wall layers and the indoor air temperature for: i) a micro ventilated façade and ii) two different ETICS solutions. The monitoring campaign has been conducted during the summer season on walls with equivalent thermal transmittance (U-value) and different thermal capacity. In detail, the experimental work has been performed to estimate the Isotec ${ }^{\oplus}$ wall micro ventilated façade performance in comparison with two traditional ETICS technology: the first one realized with EPS and the second one with high density rock wool insulation. The results show that due to the shading effect provided by the external layer, the temperature within the cavity of the ventilate façade is reduced by $8-10{ }^{\circ} \mathrm{C}$, reducing the cooling loads through the wall by $30-40 \%$ with respect to ETICS with EPS. The shading and the ventilation effects balance the presence of thermal insulation with less heat capacity; consequently, it validates the good quality of Isotec ${ }^{\circ}$ as wall technology with performances comparable to ETICS solution with high density rock wool insulation.
\end{abstract}

\section{KEYWORDS}

in situ monitoring campaign, micro ventilate façade, ETICS, performance assessment, insulation comparison

\section{INTRODUCTION.}

Improving the energy performance of buildings is crucial, not only for achieving the climate and energy goals for 2030 established within the Paris Agreement on Climate Change, but also concerning the longer-term results included in the roadmap to a low-carbon economy set as the 2050 vision [European commission, 2012]. The EU has promoted programs, projects and

1. DABC—Department of Architecture Built Environment and Construction Engineering, Politecnico di Milano, Piazza Leonardo da Vinci,32 Milano, 20133, Italy 
directives, such as the 2010/31 energy performance of buildings directive (EPBD) [European commission, 2010] and the 2012/27 on energy efficiency [European Parliament, 2012] in order to implement tools, harmonize and share criteria and technical solutions increasing the energy efficiency of existing and new buildings. In Italy, around 75\% of the total energy absorbed by the construction sector is used for the conditioning of buildings (heating and cooling) [Enea, 2014]. The reduction in energy requirements depends, in winter, mainly on the resistive qualities of the opaque envelope, while during summer on their thermal capacity. Cooling demand due to climate condition and internal thermal load is the biggest portion of a building's energy demand in a Mediterranean climate [Rossi, 2011 and Němeček et. al, 2015]. This aspect has been reiterated by the national legislation in terms of energy efficiency through the introduction of reference values regarding some "summer parameters" among these being the time shift and the attenuation factor [Ministero sviluppo economico, 2015]. The response of the envelope to the summer thermal stress is not easy to determine due to the non-stationary behavior and detailed or experimental analysis representing a good way to evaluate it. The paper presents the results of the monitoring campaign carried out in an experimental test facility assembled within the area of the Brianza Plastica Company located in Carate Brianza (Italy) composed by two test chambers (East and West for the comparison) in Cross Laminated Timber (CLT). The choice of the CLT derived, in accordance with the stakeholder, to the huge diffusion and high requests of this solution on the market for residential buildings in the Northern Italian climate. The objective of the work consists of the evaluation of the thermal behavior of two different façade technologies installed on the test boxes.

Table 1 presents a graphical summary of the scenarios set up for the whole monitoring campaign highlighting the different façade solutions for each chamber orientation and their respective observation period.

\section{STATE OF ART}

Reducing the $\mathrm{CO}_{2}$ emission of the building sector is a challenge that must be met quickly and resolutely. According to the European Directive on energy building performance (EPBD), all the new and deep renovated buildings must achieve the nearly-zero energy building standard (nZEB) by 2020 [Sesana et. al 2013] and recently the last EPBD recast-approved in June 2018 - introduced the requirement for the Member States to steadily lead the transformation of the building stock in the EU to reach nearly zero-energy performance levels by 2050 with the preparation of long-term renovation strategies (LTRS) supported by financial measures [EU 2018/844]. To reach this target, energy conservation strategies play a crucial role [Brambilla et. al, 2018]; coupling new envelope techniques [Salvalai et. al, 2017] with low energy heating/ cooling systems [Engelmann et. al, 2014] can drastically reduce the carbon emission of the building sector and increase the comfort and wellbeing of users. Considering the available market technologies, different active and passive techniques can be implemented in the design and construction of buildings, increasing their overall energy efficiency by reducing their $\mathrm{CO}_{2}$ emission. The passive heating concepts are connected mainly to the building geometry, orientation and quality of the building elements (windows, walls, and floors) since they have to collect, store, reflect, and distribute solar energy (heat) and keep it as long as possible in the indoor space. The passive cooling strategies, by contrast, have to reject the heat before its passage internally. Among different passive cooling strategies, the opaque ventilated façades represent an effective solution to prevent indoor summer overheating with a consequent reduction of cooling energy 
TABLE 1. Scenarios set up for the whole monitoring campaign with details for each chamber.

\begin{tabular}{|c|c|c|c|c|}
\hline Test no. & $\begin{array}{l}\text { West Chamber } \\
\text { Façade Solution }\end{array}$ & $\begin{array}{l}\text { Schematic } \\
\text { Design of the } \\
\text { Test Facility }\end{array}$ & $\begin{array}{l}\text { East Chamber } \\
\text { Façade Solution }\end{array}$ & $\begin{array}{l}\text { Observation } \\
\text { Period }\end{array}$ \\
\hline 1 & $\begin{array}{l}\text { ETICS facade with } \\
\text { expanded extruded } \\
\text { polystyrene EPS }\end{array}$ & 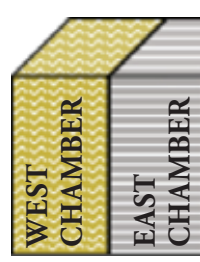 & $\begin{array}{l}\text { Micro ventilated façade } \\
\text { system with insulating } \\
\text { polyurethane } \\
\text { ISOTEC }^{\oplus} \text { wall }\end{array}$ & $\begin{array}{l}13 \text { th-28th July, } \\
2016 \text { for a total of } \\
236 \text { hours }\end{array}$ \\
\hline 2 & $\begin{array}{l}\text { ETICS facade with } \\
\text { high density mineral } \\
\text { wool insulation }\end{array}$ & 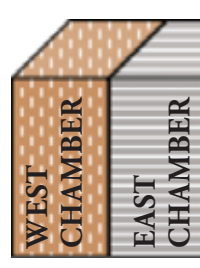 & $\begin{array}{l}\text { Micro ventilated façade } \\
\text { system with insulating } \\
\text { polyurethane } \\
\text { ISOTEC }^{\oplus} \text { wall }\end{array}$ & $\begin{array}{l}\text { 7th September- } \\
5 \text { th October, } \\
2016 \text { for a total of } \\
663 \text { hours }\end{array}$ \\
\hline 3 & $\begin{array}{l}\text { ETICS facade with } \\
\text { high density mineral } \\
\text { wool insulation }\end{array}$ & 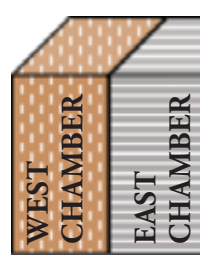 & $\begin{array}{l}\text { Micro ventilated façade } \\
\text { system with insulating } \\
\text { polyurethane } \\
\text { ISOTEC }^{\oplus} \text { wall }\end{array}$ & $\begin{array}{l}17 \text { th-27th June, } \\
2017 \text { for a total of } \\
249 \text { hours }\end{array}$ \\
\hline
\end{tabular}

demand [Ciampi et. al, 2013]. In recent years, the use of ventilated façades has gained a big share of the market with new buildings and those under renovation. Façade performance prediction is not an easy task and in literature many related studies focus on the specific application; they are case study dedicated, without a defined general methodology. Different approaches are normally used in ventilated façade technology analysis: some studies describe the different typologies of numerical modelling, highlighting their benefits and limitations [De Gracia et.al, 2013; Guillén et. al, 2014]; others have demonstrated the reduction of summer thermal loads in ventilated envelope solutions due to the direct solar radiation shield and the ventilation inside the cavity [Salvalai, 2017; Iriba-Solaberrieta et. al 2015 and Maryam et. al 2017]. Moreover, the energy saving related to double façade is strictly related to climate conditions, and it can reach values close to $51 \%$ in a temperate climate, while only $16 \%$ in a hot and humid climate [Khoshbakht et. al, 2017]. To characterize the behavior of a ventilated wall, some investigations used experimental measurements [Sanjuan et. al, 2011; Buratti et.al, 2018; Serra et. al, 2009; Stazi et. al, 2011], while others numerical methods validated by experimental results [Saferis et. al, 2011; Marinoscia et. al, 2010]. The performance evaluation has been often conducted by a comparative analysis between "traditional" and "ventilated" wall [Guillén et. al, 2014; Sanjuan et. al, 2011]. The above literature review was fundamental to set up the test box facility according to the Northern Italian climate and the characteristics of the micro ventilated façade made up with Isotec ${ }^{\oplus}$ wall (fiberboard layer with a ventilation cavity of $37 \mathrm{~mm}$ ). The experimental data have been analyzed to study the temperature levels on each layer of the different façade solution, showing the heat discharge related to the airflow within the cavity of the external finishing. The 
results presented in this paper contribute to understanding the impact of the micro ventilated façade on summer thermal comfort and cooling energy reduction.

\section{METHODOLOGY}

As the literature indicated, the application of ventilated façade technology produces several advantages. However, there is a lack of design guidelines for temperate/hot climates such as the Mediterranean. The present work contributes to filling this lack of knowledge by managing the tests inside the Brianza Plastica company area, located in Carate Brianza, (Italy) with latitude $45^{\circ} 41$ North, longitude $9^{\circ} 14$ East at an altitude of $256 \mathrm{~m}$. The experimental box is represented by two adjacent and geometrically equal chambers, built with CLT technology based on wood and with the main axis oriented according to the east-west direction. The load-bearing panels are composed of three layers of mutually crossed and glued wooden boards. The main characteristics of the wooden structure are shown below:

- thermal conductivity: $0,13 \mathrm{~W} / \mathrm{mK}$;

- coefficient of resistance to vapor diffusion $\mu$ : 50;

- density: $550 \mathrm{~kg} / \mathrm{mc}$;

- specific heat capacity: $1600 \mathrm{~J} / \mathrm{kgK}$;

From the geometrical point of view, the two chambers have a floor surface equal to $5.18 \mathrm{~m}^{2}$, while the sloped roof and the wall facing south have a surface respectively equal to $6.6 \mathrm{~m}^{2}$ and $4.6 \mathrm{~m}^{2}$. The East chamber is dedicated to the application and measurement of the performance of micro ventilated façade technology with expanded polyurethane insulation, while the West chambers have been used for testing two ETICS solutions as summarized in Table 1. Figure 1 shows the test facility building under preparation of Test 1 .

The micro ventilated façade technology has been built by installing on the wood structure the Isotec ${ }^{\oplus}$ wall $($ th. $=\mathrm{mm}$ ) coupled with fiber-reinforced concrete board (th. $=12 \mathrm{~mm}$ ). All chambers, for the three tests, have been constructed with the same plaster finishing material (th. $=4 \mathrm{~mm}$ ) with an emissivity of 0.96 . Figure 2 shows the technological axonometric projection of the three façades investigated.

FIGURE 1. Test facility box installation phase of: (left) EPS insulation (West chamber) and micro-ventilated façade with Isotec $\circledast$ wall (East chamber); (right) finishing layers equal for both chambers.

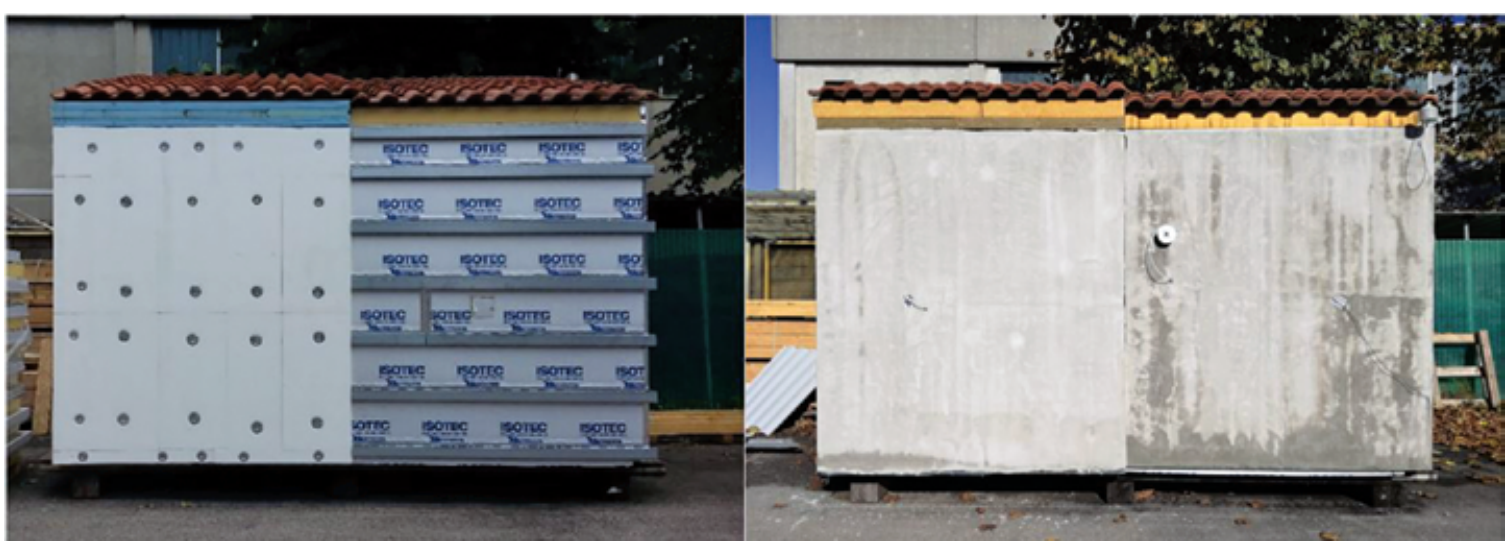


FIGURE 2. Technological axonometric projection of the three tested walls: (a) double panel in high density rock wool; (b) polyurethane foam Isotec $®$ wall; (c) double EPS insulation panel.

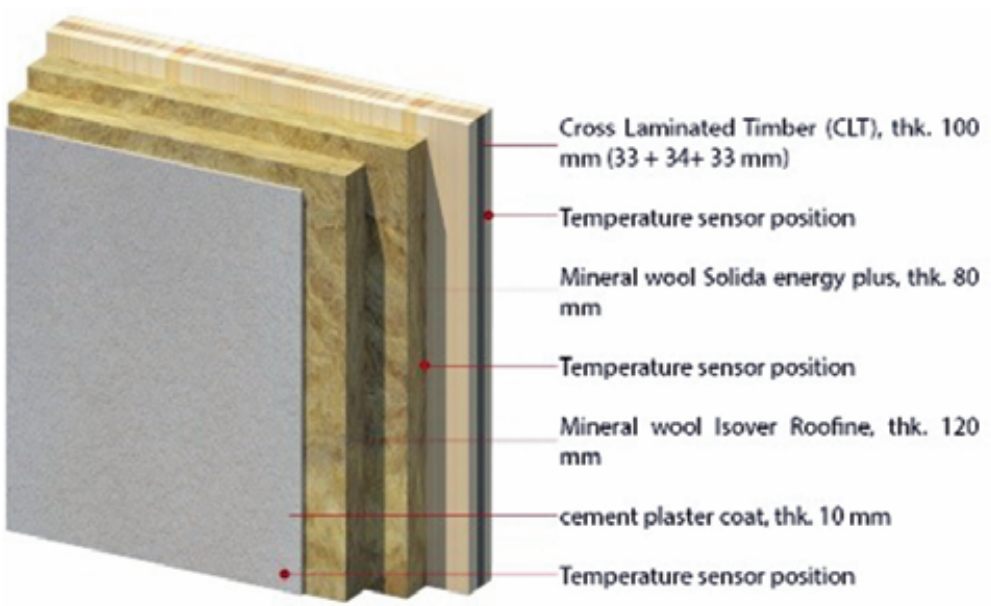

(a)

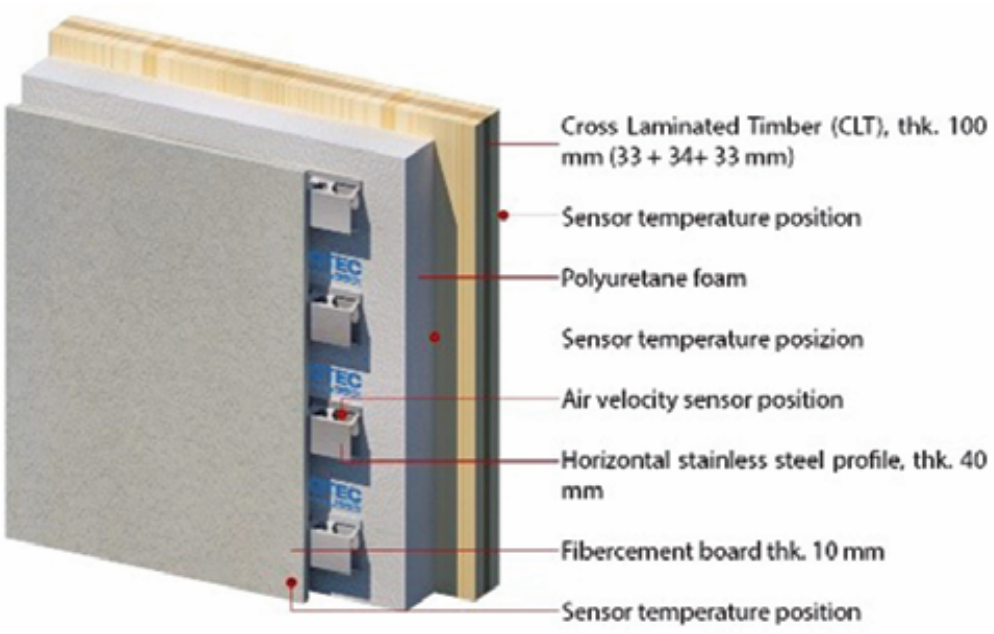

(b)

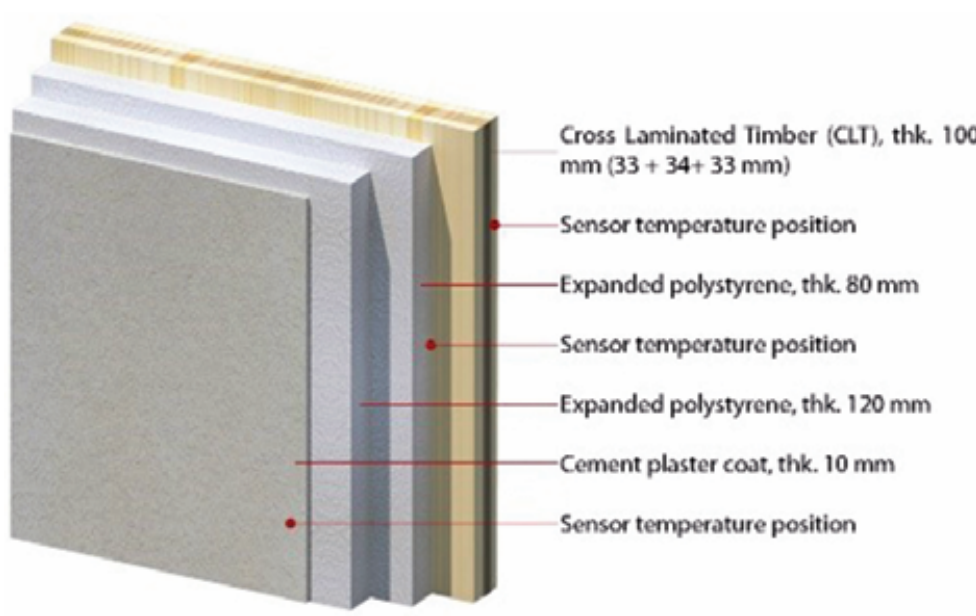

(c) 
TABLE 2. Thermal characteristics of the three façade solutions investigated.

\begin{tabular}{|l|l|l|l|l|l|l|l|}
\hline $\begin{array}{l}\text { Façade solution } \\
\text { wooden structure } \\
\text { + insulation }\end{array}$ & $\begin{array}{l}\text { Thickness } \\
{[\mathrm{mm}]}\end{array}$ & $\begin{array}{l}\mathrm{R} \\
{\left[\mathrm{m}^{2} \mathrm{~K} / \mathrm{W}\right]}\end{array}$ & $\begin{array}{l}\mathrm{U} \\
{\left[\mathrm{W} / \mathrm{m}^{2} \mathrm{~K}\right]}\end{array}$ & $\begin{array}{l}\mathrm{Y}_{\text {ie }} \\
{\left[\mathrm{W} / \mathrm{m}^{2} \mathrm{~K}\right]}\end{array}$ & $\begin{array}{l}\mathrm{F} \\
{[\mathrm{h}]}\end{array}$ & $\begin{array}{l}\text { fa } \\
{[-]}\end{array}$ & $\begin{array}{l}\mathrm{VHC} \\
{\left[\mathrm{Wh} / \mathrm{m}^{3}\right]}\end{array}$ \\
\hline $\begin{array}{l}\text { CLT + } \\
\text { polyurethane } \\
\text { insulation }\end{array}$ & 220 & 6.157 & 0.162 & 0.066 & 7.71 & 0.41 & 14.7 \\
\hline $\begin{array}{l}\text { CLT + EPS } \\
\text { insulation }\end{array}$ & 260 & 5.384 & 0.186 & 0.076 & 7.90 & 0.41 & 13.1 \\
\hline $\begin{array}{l}\text { CLT + high } \\
\text { density rockwool } \\
\text { insulation }\end{array}$ & 260 & 5.384 & 0.186 & 0.076 & 11.7 & 0.26 & 38.6 \\
\hline
\end{tabular}

The specific thermal characteristics of the walls (insulation plus wood structure) are shown in Table 2.

The measurement of the performance of the insulation systems was carried out using sensors able to detect the precise surface temperature level of the wall materials as well as the internal and external environmental conditions as represented in the schematic section of Figure 4.

The whole tests were conducted in accordance with the International Standard ISO 9836 and the ISO 9869 and ETAG 2006.

Specifically, with regard to the south face vertical wall, several surface temperature sensors were positioned in the interfaces between materials in order to record the temperature levels at different depths. The behavior of the ventilated cavity was, instead, investigated through the positioning of two hotwire anemometers, one at the base and one at the top of the wall, at a reciprocal distance of two meters, in order to measure the air flow velocity. The external environmental conditions have been detected by means of a thermo-hygrometer, for measuring the temperature and humidity of the air, and a pyranometer, positioned in adherence to the south

FIGURE 3. Zoom on thickens insulation during installation on the chambers. Left: Polyurethane foam Isotec $®$ wall; Center: EPS panel; Right: double panel in high density rock wool.
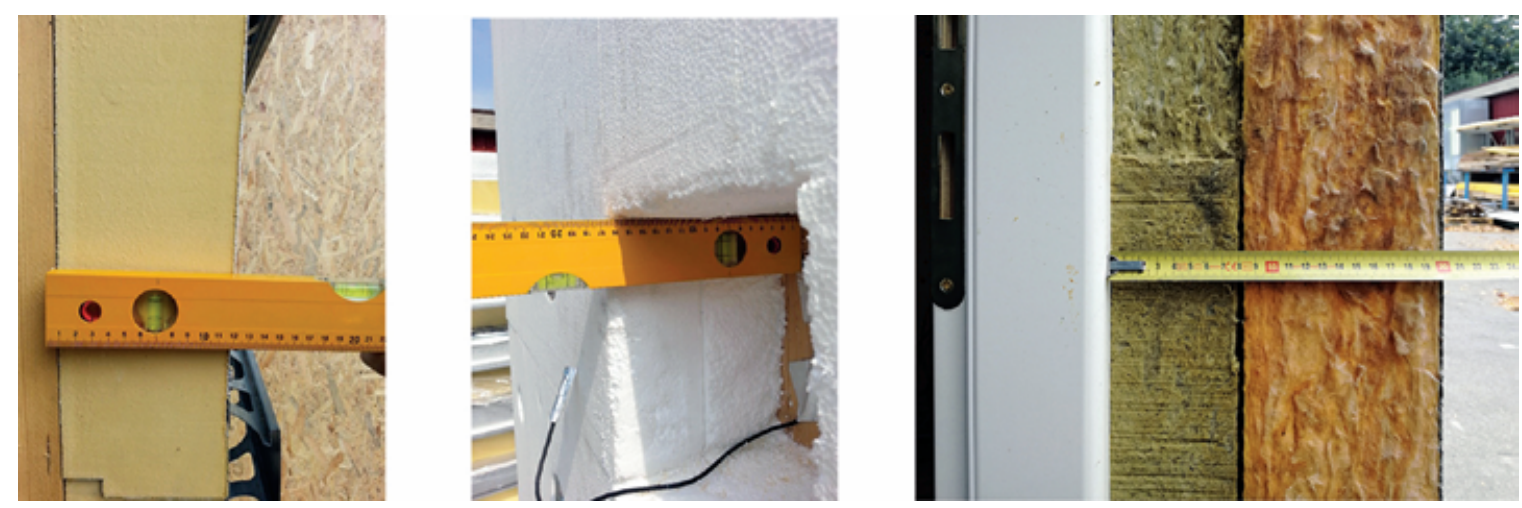
FIGURE 4. Schematic section with identification of the installed sensors.

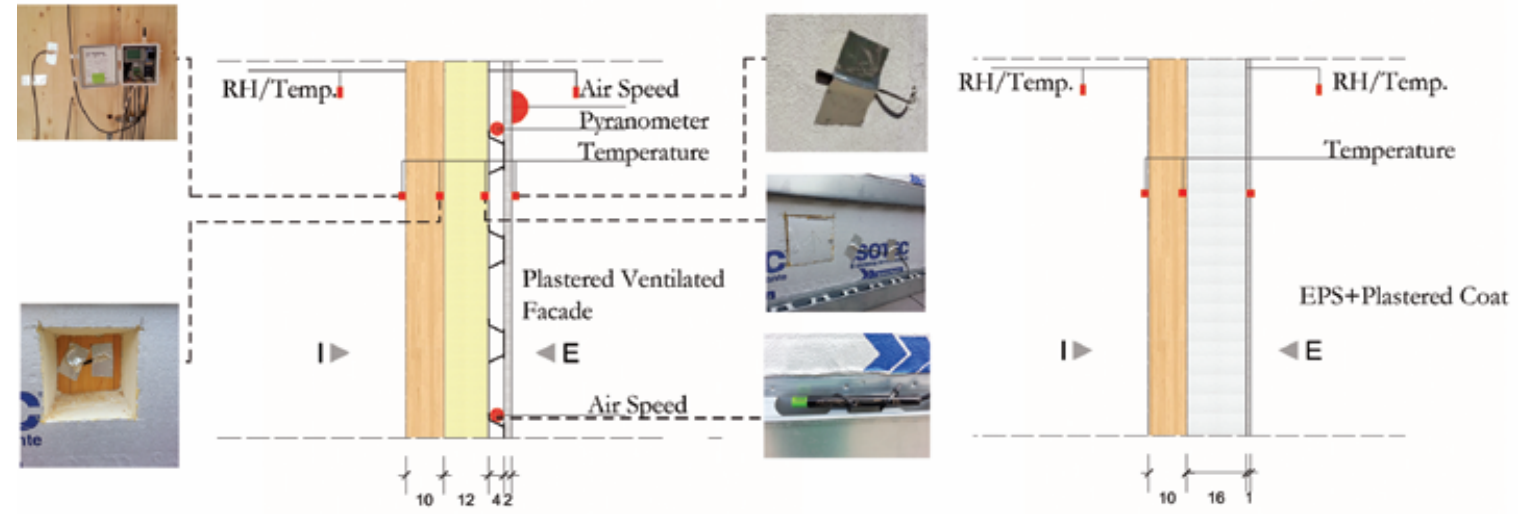

façade, to measure the global solar radiation on the vertical surface. The sensors are connected to two datalogger units accessible via web.

\section{RESULTS}

The results are first presented separately for each test performed and then in terms of comparison between the solutions investigated. Considering the micro ventilated solution, during sunny days characterized by high external ambient air temperatures $\left(34^{\circ} \mathrm{C}\right)$ and high solar radiation (higher than $450 \mathrm{~W} / \mathrm{m}^{2}$ ), the shading effect-due to the rain screen layer combined with the chimney effect of the air cavity - allows the attainment of a high temperatures attenuation between the surface temperature of the insulation layer $\left(48.07^{\circ} \mathrm{C}\right)$ with respect to the external surface $\left(56.01{ }^{\circ} \mathrm{C}\right)$, with a difference of $8{ }^{\circ} \mathrm{C}$ (Figure 5).

The thermal insulation (polyurethane foam) behind the air cavity contributes, as expected, to a further reduction of the surface temperature level of the subsequent layer represented by the wooden wall. At this point, the measured temperature level is equal to $28.82{ }^{\circ} \mathrm{C}$. In addition, considering an attenuation factor equal to 0.2 , the insulation layer allows a phase shift $(\theta)$ of about 4 hours and 30 minutes, determining the maximum thermal load in the evening hours. At that time the ambient temperature level can be suitably used for high effect natural ventilate cooling. During the night, the thermal energy release and the consequent reduction of the temperatures of the two outer layers (concrete slab and polyurethane insulation) occur simultaneously and with the same intensity, reaching the minimum level between 1 and $3 \mathrm{am}$. According to Figure 6, the minimum surface temperature of the polyurethane insulation was recorded at 2:35 am on July, 26th. This behavior demonstrates that the presence of ventilated cavity supports the discharge of absorbed energy with a consequent reduction of the temperature level for the insulation layer. Moreover, as shown in the Figure 6, the micro ventilated solution shows a temporal delay of the propagation of the thermal wave towards the wall with a difference of about two hours with respect to the EPS wall (4:50 pm for the ETICS solution and 6:50 pm for the micro ventilated façade).

The positive effect of the micro ventilation chamber is also highlighted, qualitatively and quantitatively, in the infrared image of Figure 7. The picture has been taken in a frontal position with respect to the South façade. In fact, the East chamber shows a temperature level of $4-5^{\circ} \mathrm{C}$ lower than the West chamber. 
FIGURE 5. Technological solution with micro ventilated façade. Surface temperature level graphic (a) for the wall layers (b). Time of recording: 25-27 July 2016.

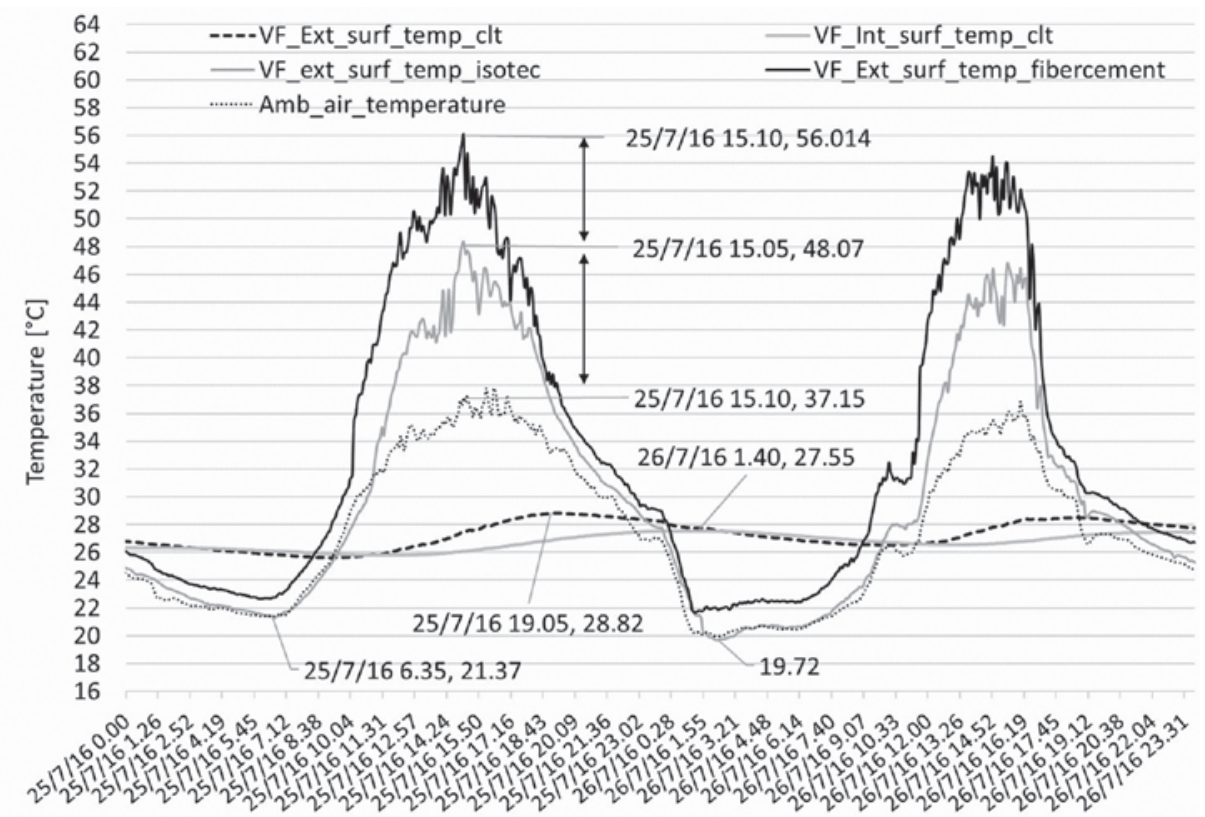

(a)

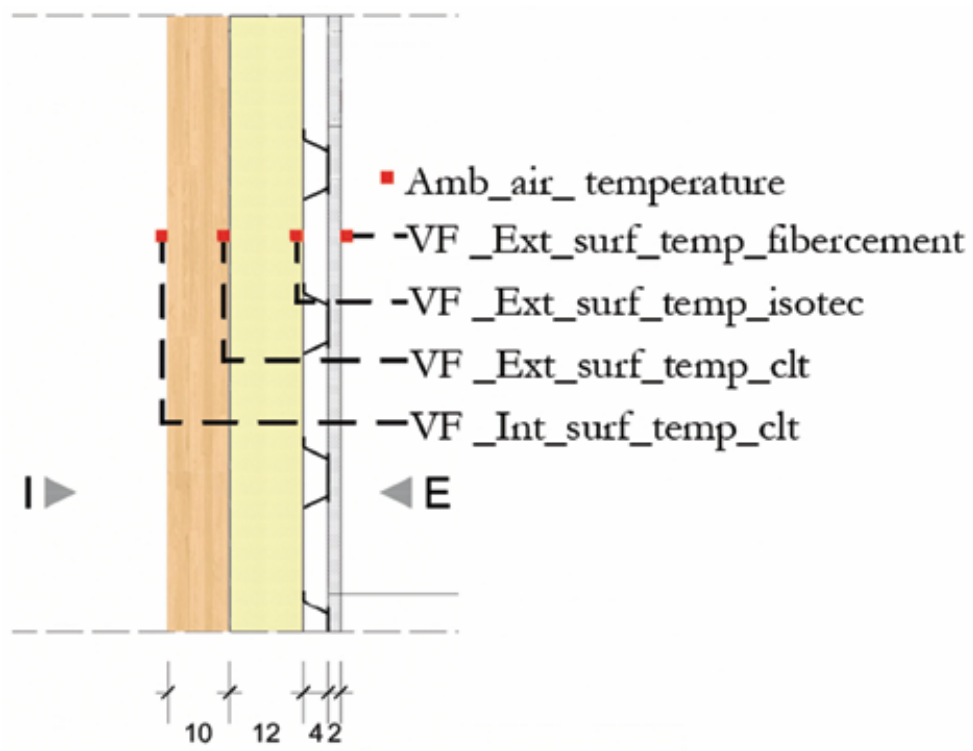

(b)

The lower temperature level registered in the micro ventilated façade is due to the chimney effect of the air cavity behind the fiber cement layer. Figure 8 shows the correlation between the air velocity and the solar radiation. As expected, due to the low dimension of the cavity, the ventilation rate is slow and the intensity increases linearly according to the increased solar radiation. The maximum value has been registered during the afternoon with an intensity of $0.2 \mathrm{~m} / \mathrm{s}$. 
FIGURE 6. Comparison of the temperature levels measured on the inner surface of the East box's insulation compared to the levels measured on the West box. Recorded time: 23-27 July 2016.

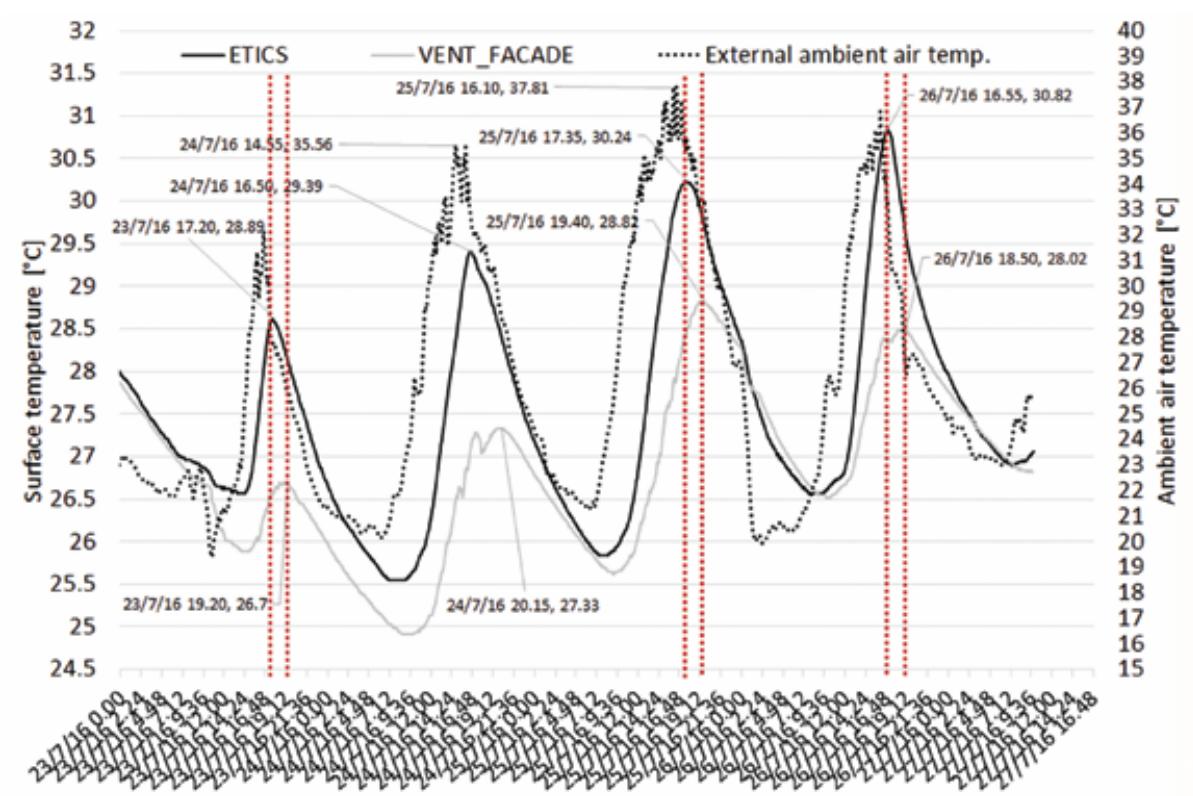

(a)

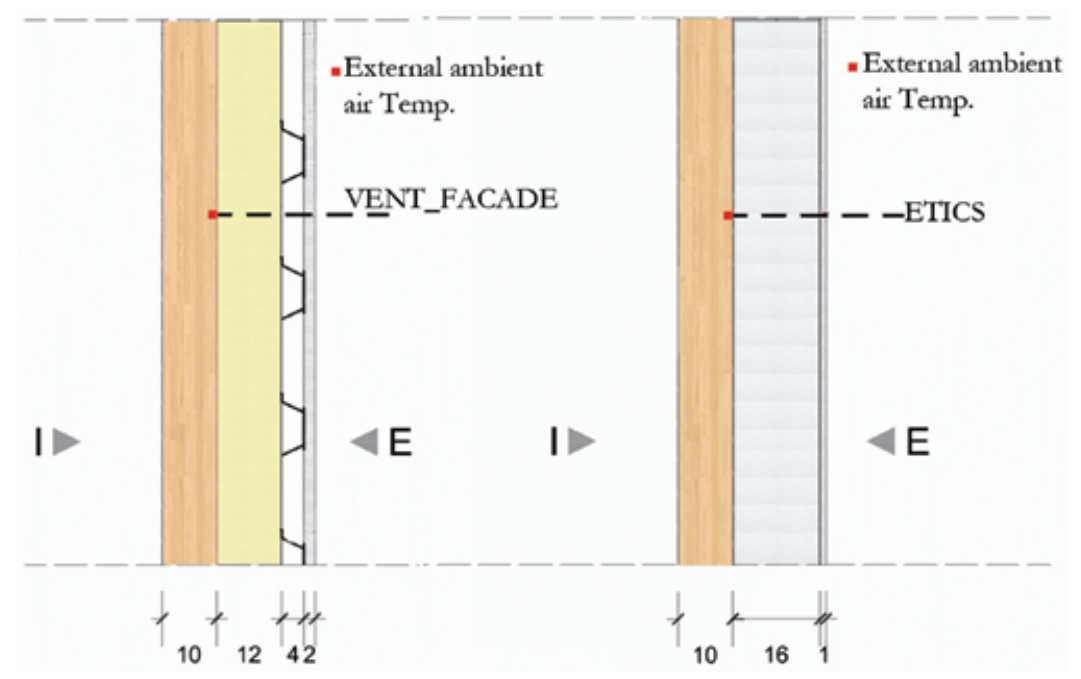

(b)

Test 2 allowed the comparison of the micro ventilated façade solution with the coat solution characterized by high density mineral wool insulation $\left(\rho=135 \mathrm{~kg} / \mathrm{m}^{3}\right.$, three times more than that of the polyurethane foam $\rho=35 \mathrm{~kg} / \mathrm{m}^{3}$ ). The reported data refer to the week between September 7 th and September 15th, characterized by typical summer temperatures and maximum average global radiation levels in the vertical plane equal to $600 \mathrm{~W} / \mathrm{m}^{2}$ ( shown in Figure 9a). The protection screen and the ventilated cavity determine together the reduction of the temperature levels in the wall layers behind the screen, compensating partially the thermal inertia difference of the insulation material. 
FIGURE 7. Analysis through Flir T640 thermal camera. Radiometric image. Comparison of the surface temperature levels of the southern face recorded on August 3rd at 10:31 (ambient relative humidity $50 \%$, ambient air temperature $29.4^{\circ} \mathrm{C}$ ). The infrared image has been calibrated using the installed surface temperature sensors.

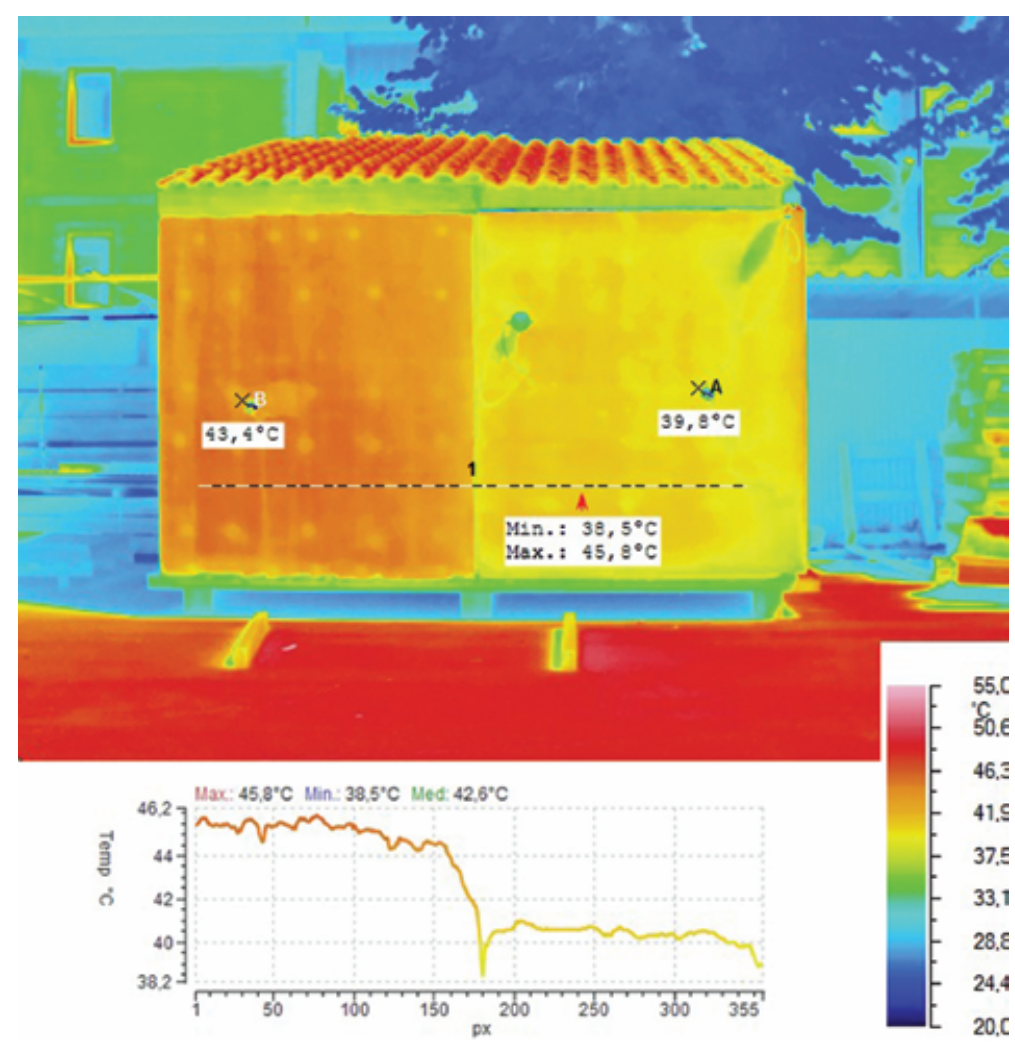

FIGURE 8. Correlation between the global radiation on the vertical south façade and the cavity air velocity.

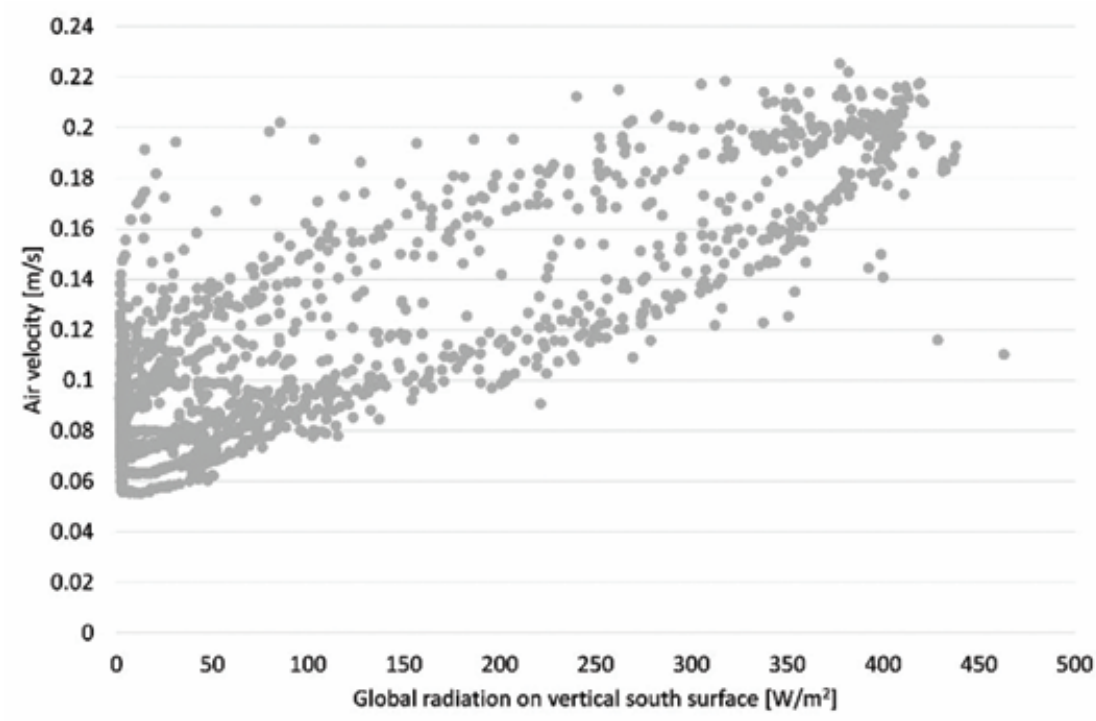


FIGURE 9. Comparison of the temperature levels measured on the inner surface of the East box's insulation compared to the levels measured on the west chamber. Recorded time: 12-15 September 2016.

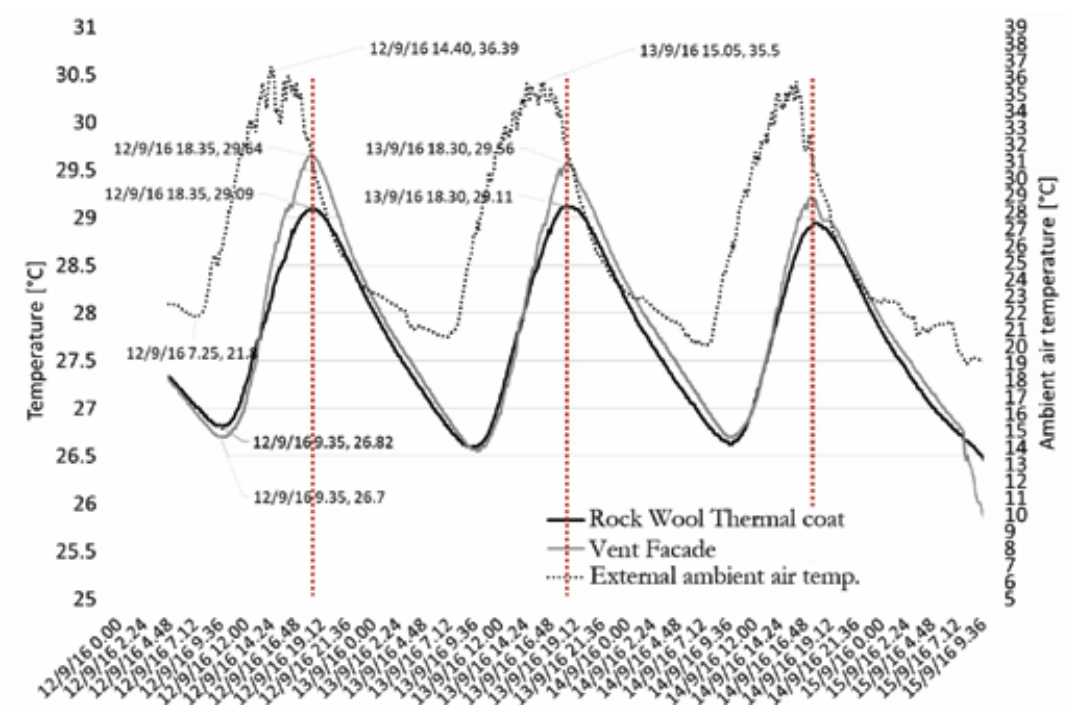

(a)

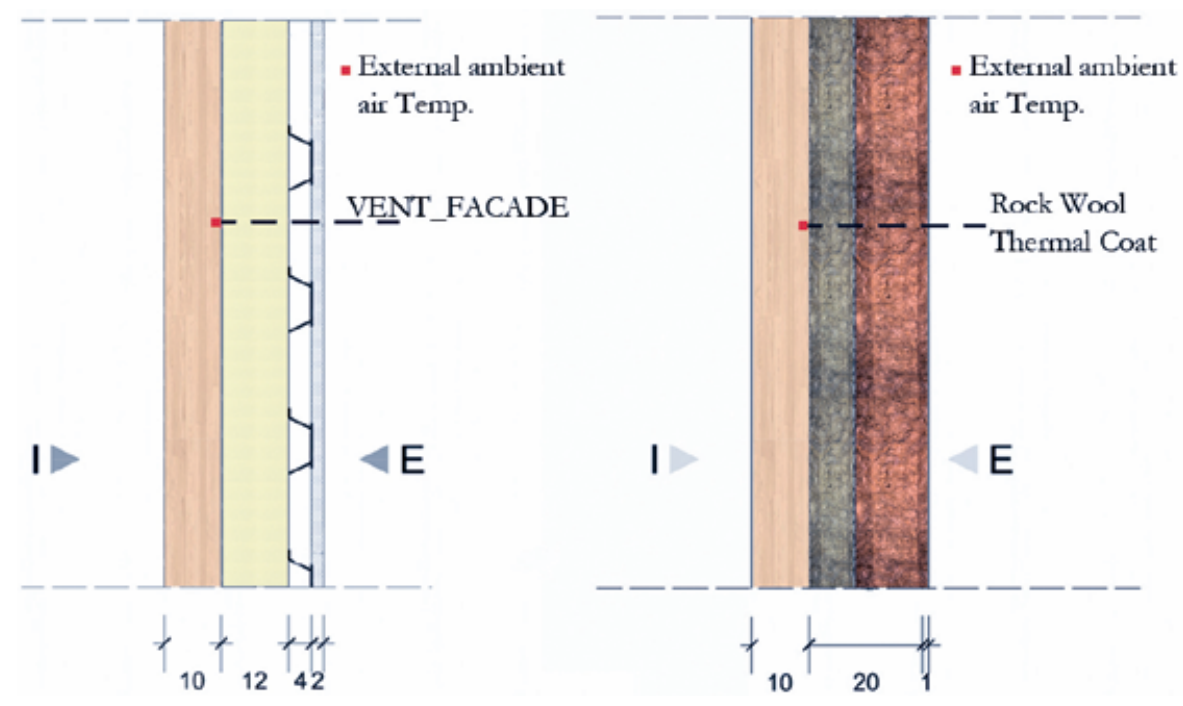

(b)

Observing the temperature level of the interface between the insulation and the CLT load bearing structure layers: the phase shift of the thermal wave is constant for both solutions and equal to 3.5 hours. The attenuation of the peak temperature, on the other hand, is slightly greater in the scenario with the rock wool insulation displaying limited differences between 0.40 and $0.60{ }^{\circ} \mathrm{C}$.

Test 3 analyses the same façade technology configuration of Test 2, but in addition, considers the effect of the mechanical night ventilation on the internal temperature levels. As shown in Figure 10, both chambers were equipped with a commercial ventilation unit, set up with a constant flow rate of $70 \mathrm{~m}^{3} / \mathrm{h}$, scheduled daily from 9:00 pm to 6:00 am. The fans have been 
FIGURE 10. North façade of the text box. The white elements are the ventilation extract fans and the ventilation grilles.
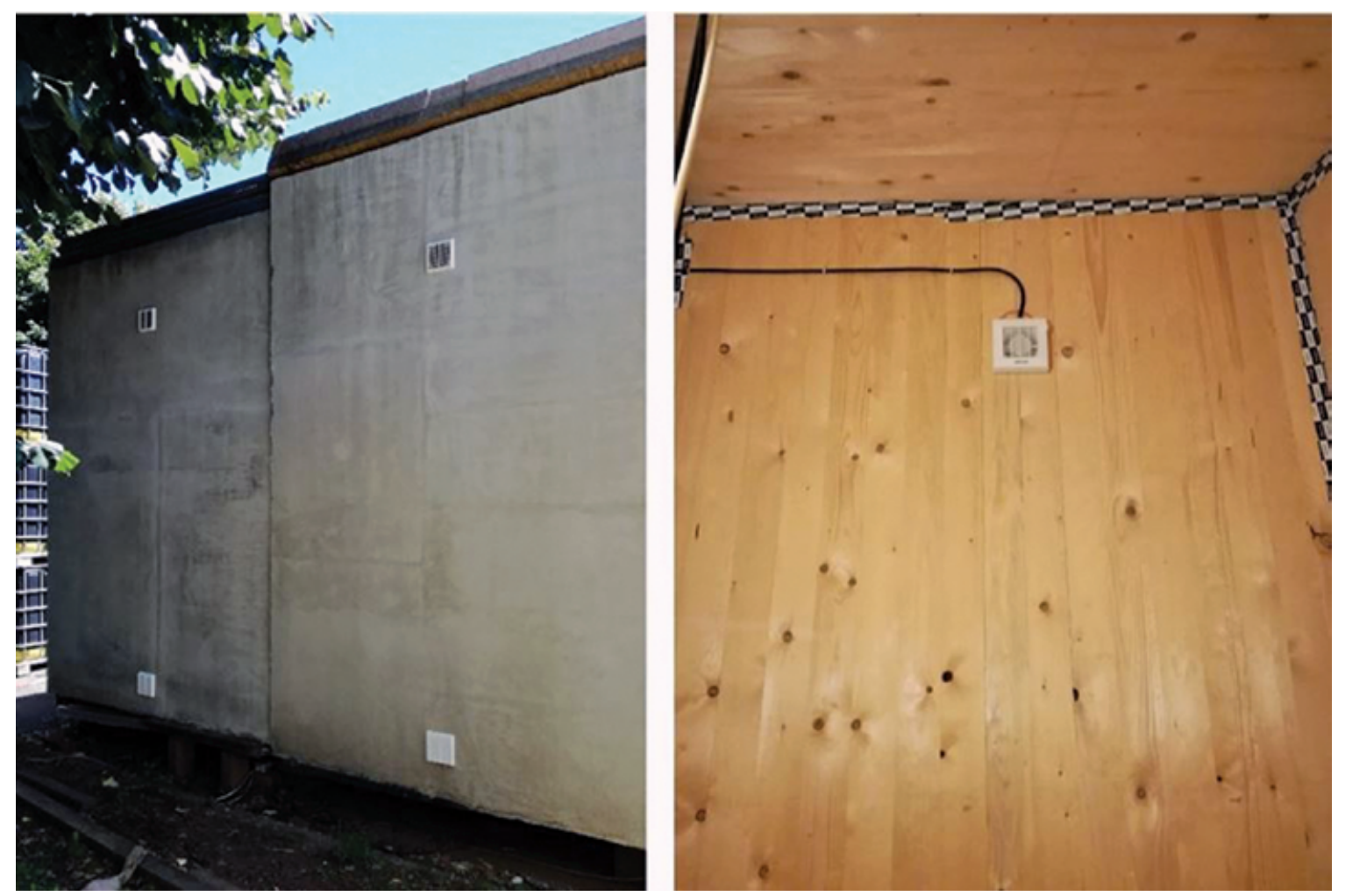

installed on the top of the north façades and the air grill on the bottom to exploit the displacement ventilation effect.

Figure 11 shows the trend of the hourly values of the internal air temperature. The data referred to two days characterized by typical summer air ambient temperature and high solar radiation (June, 18th-19th). Considering the recorded results, the temperature trend of the two walls looks similar having an equal time lag (of the temperature peak) of about $8 \mathrm{~h}$ and an attenuation factor between 0.25 and 0.30 .

Observing the temperature level during the night, when the natural ventilation is activated, the East chamber (with micro ventilated façade) shows a faster temperature reduction with respect to the West chamber (with high density rock wool insulation).

The minimum temperature level is recorded in the early morning with exactly the same temperature level for both chambers. When the ventilation stops, the West chamber shows a rapid increase of the internal air temperature due to higher heat capacity of the rock wool insulation.

\section{CONCLUSIONS}

The use of ventilated walls is becoming more and more diffuse, but their application requires a careful design. Different experimental tests were carried out in order to compare the effective performances of different wall technologies. Considering the outcomes, the micro ventilated wall can be considered an alternative solution to the "thermal coat," allowing a decrease in the 
FIGURE 11. Comparison of the surface temperature measured on the internal surface of the East box's insulation and on the internal surface of the West box with ventilation on summer night. Recorded time: 18-19 June 2017.

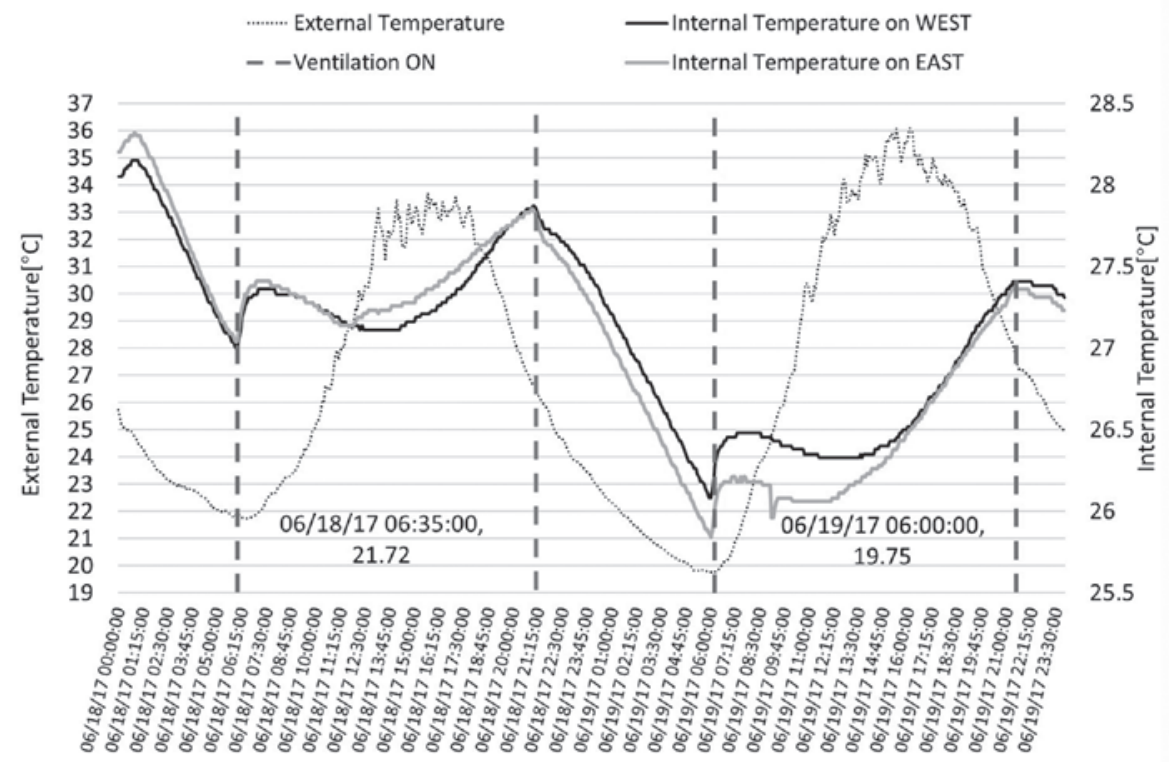

(a)
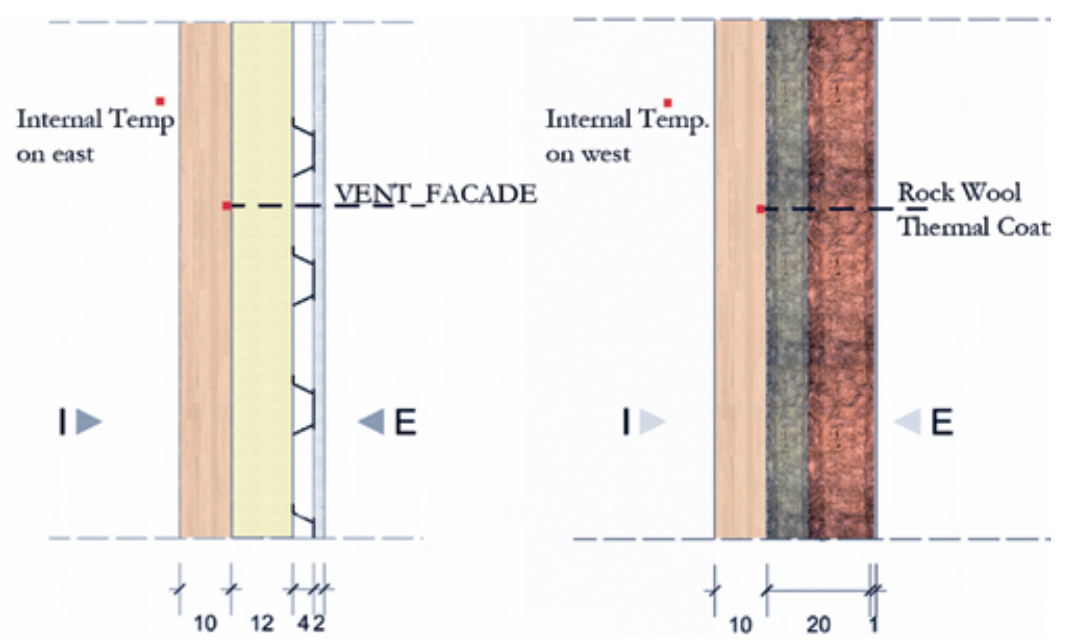

(b)

thermal stress of the wall layers during the cooling period. Following are the main results and lessons learned from the monitoring campaign on the experimental test facility equipped with the three described solutions:

- The micro ventilated façade allows high attenuation factor (fa) with values ranging from $0.2-0.3$ and time shift higher than 10 hours. 
- The external protective screen of the micro ventilated façade causes a reduction in the surface temperatures of the insulating layer between $8-12{ }^{\circ} \mathrm{C}$ on average (during days with global radiation greater than $500 \mathrm{~W} / \mathrm{m}^{2}$ in the vertical plane).

- The airspeed of the air gap varies — with liner correlation — according to the solar radiation intensity and the maximum air velocity is equal to $0.2 \mathrm{~m} / \mathrm{s}$ (with air flow rates in the cavity ranging from 0.35 and $1.5 \mathrm{l} / \mathrm{s}$ ).

- The micro ventilated solution, thanks to both the screen layer and the chimney effect, increases the phase shift of the thermal wave. Considering the inner surface temperature of the insulation layer, the maximum temperature is reached after 2 hours compared to the solution with EPS insulation.

- Test 2 shows a similar thermal behavior of the micro ventilated façade with respect to the ETICS with a high-density rock wool thermal coat. The presence of the protective screen and the air cavity of the micro ventilated façade compensates for the effect of a lower thermal capacity of the thermal insulation.

- The micro ventilated façade and the high-density rock wool thermal coat solution show a similar attenuation factor, ranging respectively from 0.2 to 0.3 for the micro ventilated façade and $0.15-0.25$ for the rock wool thermal coat.

- When the night natural ventilation is activated, the micro ventilated façade shows a faster temperature reduction with respect to that observed in the box with high density rock wool.

While this research focuses on the evaluation of the thermal performances in summer conditions, future research could focus on the longitudinal behavior study of the wall system to investigate the durability over time of the technologies and in a follow-up comparison between experimental results collected in situ with simulation results performed with building energy simulator software.

\section{ACKNOWLEDGMENTS}

The analysis described in this paper is part of the research founded by Brianza Plastica Spa on micro ventilated façade test facility.

\section{REFERENCES}

Brambilla A., Salvalai G., Imperadori, M., Sesana, M. M., Nearly zero energy building renovation: From energy efficiency to environmental efficiency, a pilot case study, Energy and Buildings, 166, 2018, pp. 271-283. doi.org/10.1016/j.enbuild.2018.02.002

Buratti, C., Palladino, D., Moretti, E., Di Palma R. Development and optimization of a new ventilated brick wall: CFD analysis and experimental validation. Energy and Buildings 168, 2018, pp. 284-297. doi: 10.1016/j. enbuild.2018.03.041.

Ciampi, M., Leccese, G., Tuoni, G., Ventilated façades energy performance in summer cooling of buildings. Solar Energy 75, 2013, pp. 491-502. doi:10.1016/j.solener.2003.09.010.

De Gracia, A., Castell, A. Navarro, L. Oró, E., Cabeza, L.F. Numerical modelling of ventilated façades: a review. Renew. Sust Energ. Rev. 22, 2013, pp. 539-549. doi: 10.1016/j.rser.2013.02.029.

Enea. 2014. Rapporto Annuale Efficienza energetica (RAEE). Igarss 2014. doi:10.1007/s13398-014-0173-7.2.

Engelmann P., Kalz D., Salvalai, G., Cooling concepts for non-residential buildings: A comparison of cooling concepts in different climate zones, Energy and Buildings, 82, 2014, pp. 447-456. doi.org/10.1016/j. enbuild.2014.07.011.

ETAG 2006, Standard for Systemized Building Envelopes, Centre for Window and Cladding Technology. 
European Parliament. 2010, Directive 2010/31/EU of 19 May 2010 on the energy performance of buildings (recast). Official Journal of the European Union: 13-35. doi:doi:10.3000/17252555.L_2010.153.eng.

European Commission. 2012. Roadmap 2050. Policy: 1-9. doi:10.2833/10759.

European Parliament. 2012. Directive 2012/27/EU. Official Journal of the European Union L315/1: 1-56. doi:10.3000/19770677.L_2012.315.eng.

Ignacio G., Gómez-Lozano V., María Fran J., López-Jiménez P. A., Thermal behavior analysis of different multilayer façade: Numerical model versus experimental prototype. Energy and Buildings 79, 2014, pp. 184-190. doi: 10.1016/j.enbuild.2014.05.006.

Iriba-Solaberrieta, E., Escudero-Revilla, E., Odriozola-Maritorena M., Campos-Celador, A., Garcìa-Gàffaro, C., Energy performance of the opaque ventilated façade, Energy Procedia 78, 2015, pp. 55-60. doi: 10.1016/j. egypro.2015.11.114

ISO 9836, third edition 2017-09, Performance standards in building-Definition and calculation area and space indicators

ISO 9869-2:2018, Thermal insulation-Building elements-In-situ measurement of thermal resistance and thermal transmittance, Part 2: Infrared method for frame structure dwelling.

Khoshbakht M., Gou Z., Dupre K., Altan H., Thermal environments of an office building with double skin façade. Journal of Green Building Sep 2017, Vol. 12, No. 3 (Summer 2017) pp. 3-22.

Marinosci C., Strachan, P.,A., Semprini, G., Morini, G.,L. Empirical validation and modelling of a naturally ventilated rainscreen façade building. Energy and Buildings 43, 2010, pp. 853-863. doi: 10.1016/j. enbuild.2010.12.005.

Ministero dello Sviluppo Economico. 2015. Linee guida nazionali per la certificazione energetica degli edifici.

Nemecek M., Kalousek M., 2015. Influence of thermal storage mass on summer thermal stability in a passive wooden house in the Czech Republic. Energy and Buildings 107, 2015, pp. 68-75. doi:10.1016/j. enbuild.2015.07.068.

Rossi M., Innovative facades lightweight and thin systems with high inertia for the thermal comfort application in office building in southern Europe. Journal of Green Building May 2011, Vol. 6, No. 2 (Spring 2011) pp. 107-121.

Salvalai, G., Misure comparative delle proprietà isolanti di diversi materiali e sistemi di facciata accoppiati a struttura in legno lamellare CLT. In G. Bernardini, E. Di Giuseppe, "Colloqui.AT.e 2017. DEMOLITION OR RECONSTRUCTION?,” Edicom edizioni, Monfalcone (Gorizia), 2017. ISBN (e-book): 978-88-9638658-3; volume cartaceo (book of abstracts) 978-88-96386-57-6.

Salvalai, G., Sesana M.M., Iannaccone G., Deep renovation of multi-storey multi-owner existing residential buildings: A pilot case study in Italy, Energy and Buildings, 148, 2017, pp. 23-36. doi.org/10.1016/j. enbuild.2017.05.011

Sanjuan C., José Suárez M., Blanco E., del Rosario Heras M., Development and experimental validation of a simulation model for open joint ventilated façades. Energy and Buildings 43, 2011, pp. 3446-3456. doi: 10.1016/j.solener.2011.04.028

Sanjuan, C., Suàrez M., J., Gonzalez, M., Pistono, J., Blanco E. Energy performance of an open-joint ventilated façade compared with a conventional sealed cavity façade. Solar Energy 85, 2011, pp. 1851-1863. doi:10.1016/j.solener.2011.04.028

Seferis, P., Strachan, P., Dimoudi, A., Androutsopoulos, A., Investigation of the performance of a ventilated wall. Energy Buildings 43, 2011, pp. 2167-2178. doi: 10.1016/j.enbuild.2011.04.023.

Serra, V., Zanghirella, F., Perino, M., Experimental evaluation of a climate façade: energy efficiency and thermal comfort performance, Energy Buildings 42, 2009, pp. 50-62. doi: 10.1016/j.enbuild.2009.07.010.

Sesana M. M., Salvalai G., Overview on life cycle methodologies and economic feasibility for nZEBs, Building and Environment, 67, 2013, pp. 211-216. doi.org/10.1016/j.buildenv.2013.05.022.

Stazi, F., F. Tomassoni, A. Vegliò, and C. Di Perna. 2011. Experimental evaluation of ventilated walls with an external clay cladding. Renewable Energy 36: 3373-3385. doi:10.1016/j.renene.2011.05.016. 
